\title{
Serological profile of John Cunningham virus (JCV) in patients with multiple sclerosis
}

\author{
Perfil sorológico do vírus John Cunningham (JCV) em pacientes com esclerose múltipla
}

Luciana Prats Branco', Tarso Adoni², Samira Luisa Apostolos-Pereira ${ }^{3}$, Joseph Bruno Bidin Brooks ${ }^{1}$, Eber Castro Correa ${ }^{4}$, Carlos Augusto Damasceno ${ }^{5}$, Audred Cristina Biondo Eboni6, Leticia Fezer7. Paulo Diniz da Gama ${ }^{8}$, Marcus Vinicius Magno Goncalves ${ }^{6}$, Sidney Gomes ${ }^{9,10}$, Anderson Kuntz Grzesiuk ${ }^{11}$, Maria Fernanda Mendes ${ }^{3}$, Rogerio Rizo Morales ${ }^{12}$, Andre Muniz ${ }^{13}$, Monica Fiuza Koncke Parolin ${ }^{14}$, Maria Lucia Vellutini Pimentel', Marlise de Castro Ribeiro ${ }^{15}$, Gutemberg Augusto Cruz dos Santos ${ }^{16}$, Henry Koiti Sato ${ }^{17}$, Simone Batista Scherpenhuijzen ${ }^{18}$, Claudio Scorcine ${ }^{1}$, Fabio Siquineli19. Nise Alexandra de Carvalho Sousa ${ }^{20}$, Daniel Lima Varela ${ }^{21}$, Tereza Cristina Avila Winckler22, Yara Dadalti Fragoso'

\begin{abstract}
Treatment options for multiple sclerosis (MS) have changed over the last few years, bringing about a new category of drugs with more efficient profiles. However, these drugs have come with a whole new profile of potential adverse events that neurologists have to learn well and quickly. One of the most feared complications of these MS treatments is progressive multifocal leukoencephalopathy caused by the reactivation of the John Cunningham virus (JCV). Objective: To identify the serologic profile of JCV in patients with MS. Methods: Data on serum antibodies for JCV were obtained using the enzyme-linked immunosorbent assay provided by the STRATIFY-JCV program. Results: A total of 1,501 blood tests were obtained from 1,102 patients with MS. There were 633 patients (57.1\%) who were positive for antibodies for JCV and 469 patients who were negative (42.9\%). Twenty-three patients became positive after initially having negative JCV antibody status. The rate of seroconversion was $18.5 \%$ over 22 months. Conclusion: The JCV serologic profile and seroconversion in Brazilian patients were similar to those described in other countries.
\end{abstract}

Keywords: multiple sclerosis; leukoencephalopathy, progressive multifocal; JC virus; natalizumab.

\footnotetext{
'Universidade Metropolitana de Santos, Departamento de Neurologia, São Paulo SP, Brasil; ${ }^{2}$ Hospital Sírio Libanês de São Paulo, Departamento de Neurologia, São Paulo SP, Brasil;

${ }^{3}$ Universidade de São Paulo, Departamento de Neurologia, São Paulo SP, Brasil;

${ }^{4}$ Clínica de Neurologia e Endocrinologia, Departamento de Neurologia, Brasília DF, Brasil;

${ }^{5}$ Universidade Federal de Juiz de Fora, Departamento de Neurologia, Juiz de Fora MG, Brasil;

${ }^{6}$ Universidade da Região de Joinville, Departamento de Neurologia, Joinville SC, Brasil;

'Santa Casa da Misericórdia do Rio de Janeiro, Departamento de Neurologia, Rio de Janeiro RJ, Brasil;

${ }^{8}$ Pontificia Universidade Católica Sorocaba, Departamento de Neurologia, Sorocaba SP, Brasil;

${ }^{9}$ Hospital Beneficencia Portuguesa, Departamento de Neurologia, São Paulo SP, Brasil;

${ }^{10}$ Hospital Paulistano, Departamento de Neurologia, São Paulo SP, Brasil;

${ }^{11}$ Clínica Neurológica, Cuiabá MT, Brasil;

${ }^{12}$ Universidade Federal de Uberlandia, Departamento de Neurologia, Uberlândia MG, Brasil;

${ }^{13}$ Hospital da Bahia, Departamento de Neurologia, Salvador BA, Brasil;

${ }^{14}$ Clínica Neurológica, Curitiba PR, Brasil;

${ }^{15}$ Universidade Federal de Ciências da Saúde de Porto Alegre, Departamento de Neurologia, Porto Alegre RS, Brasil;

${ }^{16}$ Universidade Estacio de Sá, Departamento de Neurologia, Rio de Janeiro RJ, Brasil;

${ }^{17}$ Instituto de Neurologia de Curitiba, Departamento de Neurologia, Curitiba PR, Brasil;

${ }^{18}$ Universidade Federal do Rio de Janeiro, Departamento de Neurologia, Rio de Janeiro RJ, Brasil;

${ }^{19}$ Universidade Regional de Blumenau, Departamento de Neurologia, Blumenau SC, Brasil;

${ }^{20}$ Universidade Hospital Getúlio Vargas, Departamento de Neurologia, Manaus AM, Brasil;

${ }^{21}$ Serviço de Neurologia e Neurocirurgia de Passo Fundo, Passo Fundo RS, Brasil;

${ }^{22}$ Universidade Positivo, Departamento de Neurologia, Curitiba PR, Brasil.
}

Correspondence: Yara Dadalti Fragoso; Departamento de Neurologia, Faculdade de Medicina/UNIMES; Avenida Conselheiro Nebias, 536; $11045-002$ Santos SP, Brasil. E-mail:yara@bsnet.com.br

Conflict of interest: There is no conflict of interest to declare.

Received 04 January 2018; Received in final form 09 May 2018; Accepted 30 May 2018. 


\section{RESUMO}

As opções terapêuticas para esclerose múltipla (EM) modificaram-se ao longo dos últimos anos, trazendo uma nova categoria de drogas com melhor perfil de eficácia. No entanto, estas drogas vieram com um novo perfil de potenciais eventos adversos que exigem que o neurologista os reconheça bem e rapidamente. Uma das complicações mais temidas destes tratamentos para a EM é a leucoencefalopatia multifocal progressiva (LEMP), causada pela reativação do vírus John Cunningham (JCV). Objetivo: Identificar o perfil sorológico de JCV em pacientes com EM. Métodos: Dados sorológicos de JCV foram obtidos através do ensaio por enzimas imuno-adsorvidas (ELISA) fornecido pelo programa STRATIFY-JCV. Resultados: Um total de 1.501 testes sanguíneos foram obtidos de 1.102 pacientes com EM. 0 grupo teve 633 pacientes (57,1\%) soropositivos para anticorpos anti-JCV e 469 pacientes negativos (42,9\%). Vinte e três pacientes se tornaram posivitos após resultados iniciais negativos para anticorpos anti-JCV. A taxa de soroconversão foi 18,5\% em 22 meses. Conclusão: 0 perfil sorológico do JCV e a soroconversão nos pacientes brasileiros foi semelhante àquela descrita em outros países.

Palavras-chave: esclerose múltipla; leucoencefalopatia multifocal progressiva; vírus JC; natalizumab.

The John Cunningham virus (JCV) is a ubiquitous polyoma virus that exclusively infects humans ${ }^{1}$. Primary exposure to the JCV is asymptomatic, usually occurring during childhood or adolescence, although the development of antiJCV antibodies may also occur later in life ${ }^{2}$. The JCV can be found in a latent state in several tissues, including the brain ${ }^{3}$, where it can cause progressive multifocal leukoencephalopathy (PML) in immunosuppressed patients 4 .

The advent of very potent monoclonal antibody immunological treatments for multiple sclerosis (MS) brought about a new category of patients at risk for PML ${ }^{5}$. Whereas, previously, PML was almost exclusively in patients suffering from severe immunosuppression (for example, patients with AIDS), now individuals with MS treated with natalizumab require monitoring of their JCV serum status and proper management of drug withdrawal if necessary ${ }^{6,7}$. The risk of developing PML in MS cases can be stratified, and patients at higher risk may go straight to other therapeutic options or have shorter-term treatment with natali$z^{2} \mathrm{umab}^{5}$. In the absence of an effective treatment for a devastating disease like PML, patients with MS undergoing treatment with newer drugs must be closely monitored in order to minimize central nervous system injury and to avoid severe disability ${ }^{6}$.

It is essential to ascertain the overall prevalence of the JCV in patients with MS, in order to make better use of recommendations and guidelines regarding the risk of PML. The proportion of the adult population with antibodies for the JCV seems to vary between $50 \%$ and $90 \%^{8}$. A previous Brazilian study found that $51.2 \%$ out of 168 patients with MS were seropositive for the JCV ${ }^{9}$. The objective of the present study was to assess a much larger Brazilian population of patients with MS regarding seropositivity for the JCV.

\section{METHODS}

This study was approved by the Ethics Committee of Universidade Metropolitana de Santos under the number CAAE 05669912.3.0000.5509. Additional approval from other MS centers was obtained, whenever necessary, by the participating neurologists.
Serum antibodies for the JCV were detected using the enzyme-linked immunosorbent assay. This test was always performed by the same laboratory and was done in accordance with the STRATIFY-JCV program (Biogen Idec, Cambridge, MA, USA). The results were analyzed in a descriptive manner and were presented as median values. Fisher's exact test and Pearson's correlation were assessed using SPSS 24.0 software.

\section{RESULTS}

A total of 1,501 blood tests were obtained from 1,102 patients with MS over five years (2012 to 2017). There were 793 women and 314 men (2.5:1); and the patients' median age was 38 years. The patients underwent a variety of therapies and not all of them used (or had previously used) natalizumab for MS control.

In a cross-sectional analysis in October 2017, 633 patients (57.1\%) were found to be positive for antibodies for the JCV and 469 patients were negative (42.9\%). Twenty-three patients became positive after initially having negative JCV antibody status. Therefore, at the beginning of the assessment (2012), there were 610 JCV-positive patients (55.3\%) and 592 patients who had tested negative at least once (54.7\%). Men were significantly more prone to having a JCV-positive status $(\mathrm{p}<0.001)$, while age did not influence results $(\mathrm{r}=0.115)$.

Taking into consideration the 124 seronegative patients who had had more than one JCV test, seroconversion occurred in 23 cases $(18.5 \%)$ over a median period of 22 months. Seroconversion was not associated with the patient's age or sex. Because the number of patients who were negative for the JCV and converted to positive was small $(n=23)$, it was not possible to conduct further analysis on all factors that might potentially affect seroconversion (for example, previous therapies).

\section{DISCUSSION}

The rate of seropositivity for anti-JCV antibodies in the Brazilian population of patients with MS seems to have 
remained stable in relation to a previous study published five years ago9. The cross-sectional prevalence of Brazilian JCV-seropositive patients with MS increased from 51.8\% (n $=186)$ in $2012-2013$ to $57.1 \%(\mathrm{n}=1,102)$. This difference was not significant ( $\mathrm{p}=0.09$ ), and these prevalence values are in line with those reported by other authors ${ }^{10,11}$. A recent review of the worldwide prevalence of the JCV in patients with MS and neuromyelitis optica included data from 26 countries ${ }^{11}$. The median prevalence around the world was the same as in the present Brazilian study (57.1\%) and the range of positive results for JCV antibodies was $40 \%$ to $69 \%^{11}$. The fact that data on this subject are now being analyzed and reported in so many countries emphasizes the importance of this matter.

The rate of JCV seroconversion in Brazilian patients with MS is similar to that reported in other countries. Seroconversion occurred in $15.9 \%$ of the patients over a period of 14.8 months $^{12}$, in $14.5 \%$ after 12 months $^{13}$, $17.6 \%$ over 18 months ${ }^{14}$ and $26.7 \%$ over an average period of 43 months ${ }^{15}$. In a recently published review of data in the literature, which included two large cohort studies, the seroconversion rate per year was $10.8 \%^{16}$. On the other hand, other researchers have described much lower seroconversion rates: for example, in only $5.8 \%$ of the patients in Portugal after five years ${ }^{17}$.

Regarding the correlation between natalizumab use and seroconversion, it has been shown that the serum levels of natalizumab were not associated with the JCV antibody status, JCV antibody index or seroconversion ${ }^{18}$. Other authors have reported different results and have correlated use of natalizumab with seroconversion to $\mathrm{JCV}^{19}$. In fact, a recent longitudinal study showed seroconversion to be $11.5 \%$, but there were also high numbers of intermittently seropositive cases $(9.7 \%)$ and seroreverters $(3.6 \%)^{20}$. The JCV serostatus stability was not influenced by age, sex, disease duration or number of natalizumab infusions ${ }^{20}$. The predictive factor for JCV stability was the baseline anti-JCV antibody index ${ }^{21}$. When the index was higher than 0.9, it predicted stable positive serostatus (sensitivity $88.7 \%$, specificity $96.5 \%$ ), and when it was lower than 0.2 , it predicted stable negative serostatus (sensitivity $61.3 \%$, specificity $97.6 \%)^{21}$.

The present study did not assess serum levels of natalizumab nor did it obtain detailed data regarding its use as therapy for MS. The potential influence of MS treatments on seroconversion was not considered in the present analyses and will be addressed in further (and larger) population studies. Likewise, the serum index of anti-JCV antibodies will be assessed from now on by the Brazilian group as a potential predictive factor for JCV serostatus stability. These were limitations to our study as a small number of seroconverters were identified, and these could not be studied in further detail.

In conclusion, seropositivity for and seroconversion to JCV in Brazilian patients are similar to those described in other countries. The high number of epidemiological studies similar to ours reinforces the concerns regarding the matter of the JCV, PML and MS.

\section{References}

1. Tan CS, Koralnik IJ. Progressive multifocal leukoencephalopathy and other disorders caused by JC virus: clinical features and pathogenesis. Lancet Neurol. 2010 Apr;9(4):425-37. https://doi.org/10.1016/S1474-4422(10)70040-5

2. Engels EA, Rollison DE, Hartge P, Baris D, Cerhan JR, Severson RK et al. Antibodies to JC and BK viruses among persons with non-Hodgkin lymphoma. Int J Cancer. 2005 Dec;117(6):1013-9. https://doi.org/10.1002/ijc.21277

3. Tan CS, Ellis LC, Wüthrich C, Ngo L, Broge TA Jr, Saint-Aubyn J et al.JC virus latency in the brain and extraneural organs of patients with and without progressive multifocal leukoencephalopathy. J Virol. 2010 Sep;84(18):9200-9. https://doi.org/10.1128/JVI.00609-10

4. Koralnik IJ. Progressive multifocal leukoencephalopathy revisited: has the disease outgrown its name? Ann Neurol. 2006 Aug;60(2):162-73. https://doi.org/10.1002/ana.20933

5. McGuigan C, Craner M, Guadagno J, Kapoor R, Mazibrada G, Molyneux Pet al. Stratification and monitoring of natalizumab-associated progressive multifocal leukoencephalopathy risk: recommendations from an expert group.J Neurol Neurosurg Psychiatry. 2016 Feb;87(2):117-25.

6. Major EO, Yousry TA, Clifford DB. Pathogenesis of progressive multifocal leukoencephalopathy and risks associated with treatments for multiple sclerosis: a decade of lessons learned. Lancet Neurol. 2018 May;17(5):467-80. https://doi.org/10.1016/S1474-4422(18)30040-1

7. Grabowski MK, Viscidi RP, Margolick JB, Jacobson LP, Shah KV. Investigation of pre-diagnostic virological markers for progressive multifocal leukoencephalopathy in human immunodeficiency virus-infected patients. J Med Virol. 2009 Jul;81(7):1140-50. https://doi.org/10.1002/jmv.21493
8. Bellizzi A, Anzivino E, Rodio DM, Palamara AT, Nencioni L, Pietropaolo V. New insights on human polyomavirus $\mathrm{JC}$ and pathogenesis of progressive multifocal leukoencephalopathy. Clin Dev Immunol. 2013;2013:839719. https://doi.org/10.1155/2013/839719

9. Fragoso YD, Mendes MF, Arruda WO, Becker J, Brooks JB, Carvalho $\mathrm{MJ}$ et al. Nearly one-half of Brazilian patients with multiple sclerosis using natalizumab are DNA-JC virus positive. Arq Neuropsiquiatr. 2013 Oct;71(10):780-2. https://doi.org/10.1590/0004-282X20130121

10. Bozic C, Subramanyam M, Richman S, Plavina T, Zhang A, Ticho B. Anti-JC virus (JCV) antibody prevalence in the JCV Epidemiology in MS (JEMS) trial. Eur J Neurol. 2014 Feb;21(2):299-304. https://doi.org/10.1111/ene.12304

11. Paz SP, Branco L, Pereira MA, Spessotto C, Fragoso YD. Systematic review of the published data on the worldwide prevalence of John Cunningham virus in patients with multiple sclerosis and neuromyelitis optica. Epidemiol Health. 2018 Jan;40:e2018001. https://doi.org/10.4178/epih.e2018001

12. Schwab N, Schneider-Hohendorf T, Pignolet B, Breuer J, Gross CC, Göbel K et al. Therapy with natalizumab is associated with high JCV seroconversion and rising JCV index values. Neurol Neuroimmunol Neuroinflamm. 2016 Jan;3(1):e195. https://doi.org/10.1212/NXI.0000000000000195

13. Outteryck O, Zéphir H, Salleron J, Ongagna JC, Etxeberria A, Collongues $\mathrm{N}$ et al.JC-virus seroconversion in multiple sclerosis patients receiving natalizumab. Mult Scler. 2014 Jun;20(7):822-9. https://doi.org/10.1177/1352458513505353

14. Alroughani R, Akhtar S, Ahmed SF, Khoury SJ, Al-Hashel JY, Sahraian MA et al. JC virus seroprevalence and seroconversion in multiple sclerosis cohort: A Middle-Eastern study.J Neurol Sci. 2016 Jan;360:61-5. https://doi.org/10.1016/j.jns.2015.11.044 
15. Vennegoor A, van Rossum JA, Leurs C, Wattjes MP, Rispens T, Murk $J L$ et al. High cumulative JC virus seroconversion rate during longterm use of natalizumab. Eur J Neurol. 2016 Jun;23(6):1079-85. https://doi.org/10.1111/ene.12988

16. Schwab N, Schneider-Hohendorf T, Hoyt T, Gross CC, Meuth SG, Klotz Let al. Anti-JCV serology during natalizumab treatment: review and meta-analysis of 17 independent patient cohorts analyzing anti-John Cunningham polyoma virus seroconversion rates under natalizumab treatment and differences between technical and biological seroconverters. Mult Scler. 2018 Apr;24(5):563-73. https://doi.org/10.1177/1352458517728814

17. Correia I, Jesus-Ribeiro J, Batista S, Martins Al, Nunes C, Macário MC, et al. Anti-JCV antibody serostatus and longitudinal evaluation in a Portuguese Multiple Sclerosis population. J Clin Neurosci. 2017 Nov;45:257-60. https://doi.org/10.1016/j.jocn.2017.08.006
18. van Kempen ZL, Leurs CE, de Vries A, Vennegoor A, Rispens T, Wattjes MP, et al. John Cunningham virus conversion in relation to natalizumab concentration in multiple sclerosis patients. Eur J Neurol. 2017 Sep;24(9):1196-9. https://doi.org/10.1111/ene.13355

19. Peters J, Williamson E. Natalizumab therapy is associated with changes in serum JC virus antibody indices over time. J Neurol. 2017 Dec;264(12):2409-12. https://doi.org/10.1007/s00415-017-8643-4

20. Alroughani R, Akhtar S, Ahmed S, Al-Hashel J. A longitudinal study of JC virus serostatus stability among multiple sclerosis patients. Mult Scler Relat Disord. 2018 Feb;20:132-5. https://doi.org/10.1016/j.msard.2018.01.016

21. Hegen H, Auer M, Bsteh G, Di Pauli F, Plavina T, Walde J, et al. Stability and predictive value of anti-JCV antibody index in multiple sclerosis: A 6-year longitudinal study. PLoS One. 2017 Mar;12(3):e0174005. https://doi.org/10.1371/journal.pone.0174005 